\title{
Foraminiferal Biostratigraphy of Bekhme Formation (Late Campanian) in Dohuk Area/ Northern Iraq
}

\author{
Majid M. Al-Mutwali Layla Y. Al-Haidary \\ Department of Geology \\ College of Science \\ University of mosul
}

(Received 30/11/2011, Accepted 7/5/2012)

\begin{abstract}
The lithology and biostratigraphy of Bekhme Formation and lower part of Shiranish Formation have been investigated within a well - exposed section at the southern limb of Bekhair anticline, Dohuk area, north of Iraq. The section consists of marly limestone, limestone, conglomerate and marl. The lower contact of Bekhme Formation is not exposed in the studied area. The upper contact is unconformably overlain by the Shiranish Formation which consists of marl, limestone and marly limestone.The sequences of the section are characterized by rich foraminiferal faunas, where forty - eight planktonic species belonging to fourteen genera besides fifty - three benthonic species and subspecies belonging to forty genera have been recognized. The study of planktonic foraminifera resulted in the recognition of four biozones, these are from older at base:

4- Gansserina gansseri Interval Zone (part) (CF7).

3- Globotruncana aegyptiaca Interval Zone (CF8).

2- Globotruncanita stuarti - stuartiformis Partial Range Zone (CF9).

1- Globotruncanita calcarata Total Range Zone (part) (CF10).

The larger benthonic foraminiferal fauna, which appears within five stratigraphic intervals permits the recognition of: Orbitoides mediusLepidorbitoides minor Assemblage Zone. Planktonic and benthonic zones were correlated with other zonal schemes in and outside Iraq. The studied section is appeared within late Campanian age.
\end{abstract}

Key words: Bekhme Formation, Late Campanian, Planktonic Foraminifera, Zone.

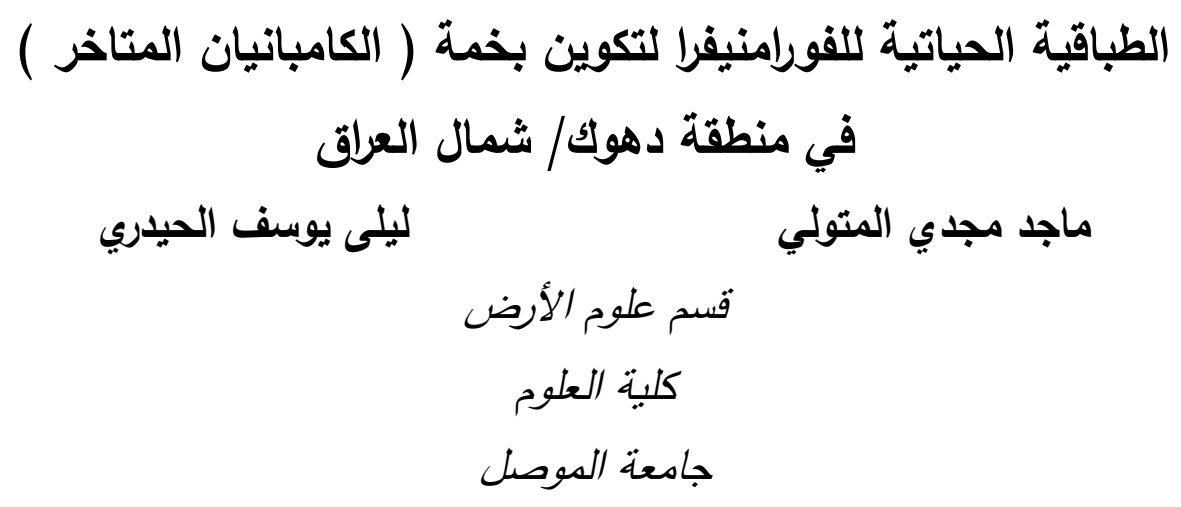




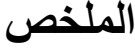

درست الطباقية الصخرية والحياتية لتكوين بخمة والجزء السفلي من تكوين شرانش ضمن احد المقاطع السطحية التي ينكثف فيها النكوين على الطرف الجنوبي لطية بيخير المحدبة في منطقة دهوك، شمال العراق. تتألف تتابعات المقطع من الحجر الجيري المارلي والحجر الجيري والمدملكات والمارل. حد التماس السفلي لتكوين بخمة غير منكثف في منطقة الدراسة، أما حد التماس العلوي يكون غير منوافق طباقياً مع تكوين شرانش الذي يتالف من المارل والحجر الجيري والحجر الجيري المارلي. تتميز تتابعات المقطع بوفرة

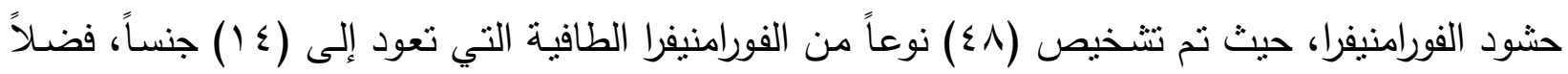

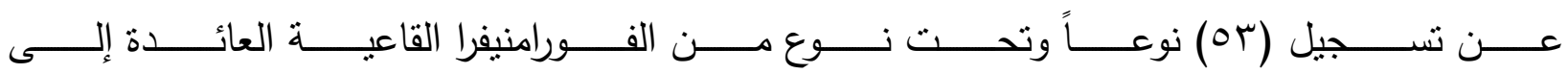
( • عنساً. واعتماداً على حشود الفورامنيفرا الطافية قسمت نتابعات المقطع إلى أربعة أنطقه حياتية وهذه الأنطقة هي كالأتي من الأقدم في الاسفل :

4- Gansserina gansseri Interval Zone (part) (CF7).

3- Globotruncana aegyptiaca Interval Zone (CF8).

2- Globotruncanita stuarti - stuartiformis Partial Range Zone (CF9).

1- Globotruncanita calcarata Total Range Zone (part) (CF10).

تم تحديد نطـاق للفورامنيفرا القاعيـة الكبيرة التي يتكرر ظهورهـا في خمسـة مستويات طباقيـة ممنلـة بالنطاق "Orbitoides medius - Lepidorbitoides minor Assemblage Zone" وتمت مظاهاة الانطقة الموصوفة في هذا المقطع مع مثيلاتها داخل العراق وخارجه وأظهرت أن المقطع المدروس هو بعر

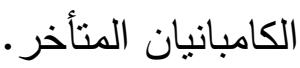

\section{INTRODUCTION}

The type section of Bekhme Formation was first defined and described by (Wetzel, 1950) in Bellen et al. (1959) from Bekhme Gorge along the Greater Zab River in the High Folded Zone, northeast Iraq. It attains a thickness of $315 \mathrm{~m}$ and its lower part is (10 m thick) consists of foraminiferal limestones and polygenetic breccia - conglomerates, with locally ferruginous marl, whereas the middle part ( $94 \mathrm{~m}$ thick ) is recognized informally as «Cosinella zone» comprising of reef detrital limestones with rudist debris, alternating with fore - reef shoal limestones with rich foraminiferal fauna. The upper part $(211 \mathrm{~m}$ thick $)$ is composed of bituminous secondary dolomites with dispersed glauconite, replacing glauconitic, organic, detrital limestones, some globigerinal limestone intercalations with macrofossil detritus. Bekhme Formation has a relatively limited distribution where it is exposed in the High Folded Zone between the Greater Zab and Rawanduz Rivers in the east and the Turkish - Syrian - Iraqi borders along the Hazil Su River to the west. Towards the east and southeast of the Rawanduz area the formation rapidly wedges out and is surely recognized down to Ranya area. Further to the 
east the formation occurs in the form of tongues within Shiranish or Tanjero Formations (Buday, 1980). Generally, the thickness of the formation is reduced towards Turkish and Syrian borders (Buday, 1980). Chatton and Hart (1961) mentioned that the Bekhme Formation represents the neritic facies that was deposited during late Campanian - Maastrichtian cycle. This cycle witnesses a climax of the obduction and closure of the southern Neo - Tethys, this event contributed to a major transgression across the whole of Iraq. The paleogeographic map of this cycle shows that the Bekhme Formation was deposited on a carbonate platform that developed over the Qamchuqa ridge, while Shiranish Formation was deposited in outer shelf to basinal environments ( Jassim and Buday, 2006 ). The studied section is located on the southern limb of Bekhair anticline, $5 \mathrm{~km}$ north of Dohuk city. The beginning coordinates of the section studied are $36^{\circ} 53^{\prime} 51^{\prime \prime} \mathrm{N}$ latitude, $43^{\circ} 00^{\prime} 53^{\prime \prime} \mathrm{E}$ longitude, and the coordinates at the end of the section are $36^{\circ} 53^{\prime} 45^{\prime \prime} \mathrm{N}$ latitude, $43^{\circ} 00^{\prime} 45^{\prime \prime} \mathrm{E}$ longitude (Fig. 1). The main purpose of this study is to establish the biostratigraphic zones and to correlate them with the equivalent biozones in and outside of Iraq, in order to determine the age of the studied section.

\section{LITHOLOGY AND CONTACT BOUNDARIES}

Bekhme Formation at the studied area is $76 \mathrm{~m}$ thick and is composed of alternations of marly limestone, limestone, conglomerate and thin beds of marl as shown in (Fig. 2). The lower part of the formation consists of marly limestone and two beds of conglomerate (Fig. 3a), which are intercalated with one limestone bed, while the top of the formation is terminated by thick beds of conglomerates and limestone bed with two hardground surfaces, which contain a prominent traces of borings (Fig. 3f). Hardground surface represents the boundary between Bekhme Formation and the overlaying Shiranish Formation, which represents the uppermost $(7 \mathrm{~m})$ of the studied section. The lower part of Shiranish Formation consists of thick beds of soft marls intercalated with thin to medium bedded limestone and marly limestone beds. The lower contact of the Bekhme Formation is not exposed in the studied section. Many previous studies, like Bellen et al. (1959) mentioned that this contact in the type section is unconformable with underlying Qamchuqa Formation. The upper contact is unconformable with the Shiranish Formation, which is indicated by two field observations: First, the sudden change in lithology between the two formations from the brownish massive limestone beds of Bekhme Formation to the bluish gray marl of Shiranish Formation. Second, the presence of two hardground surfaces on the top of Bekhme Formation. The occurrence of these borings indicates a slow or break in sedimentation that led to consolidation of sea floor sediments and then forming a hardground surfaces. 
Majid M. Al-Mutwali and Layla Y. Al-Haidary

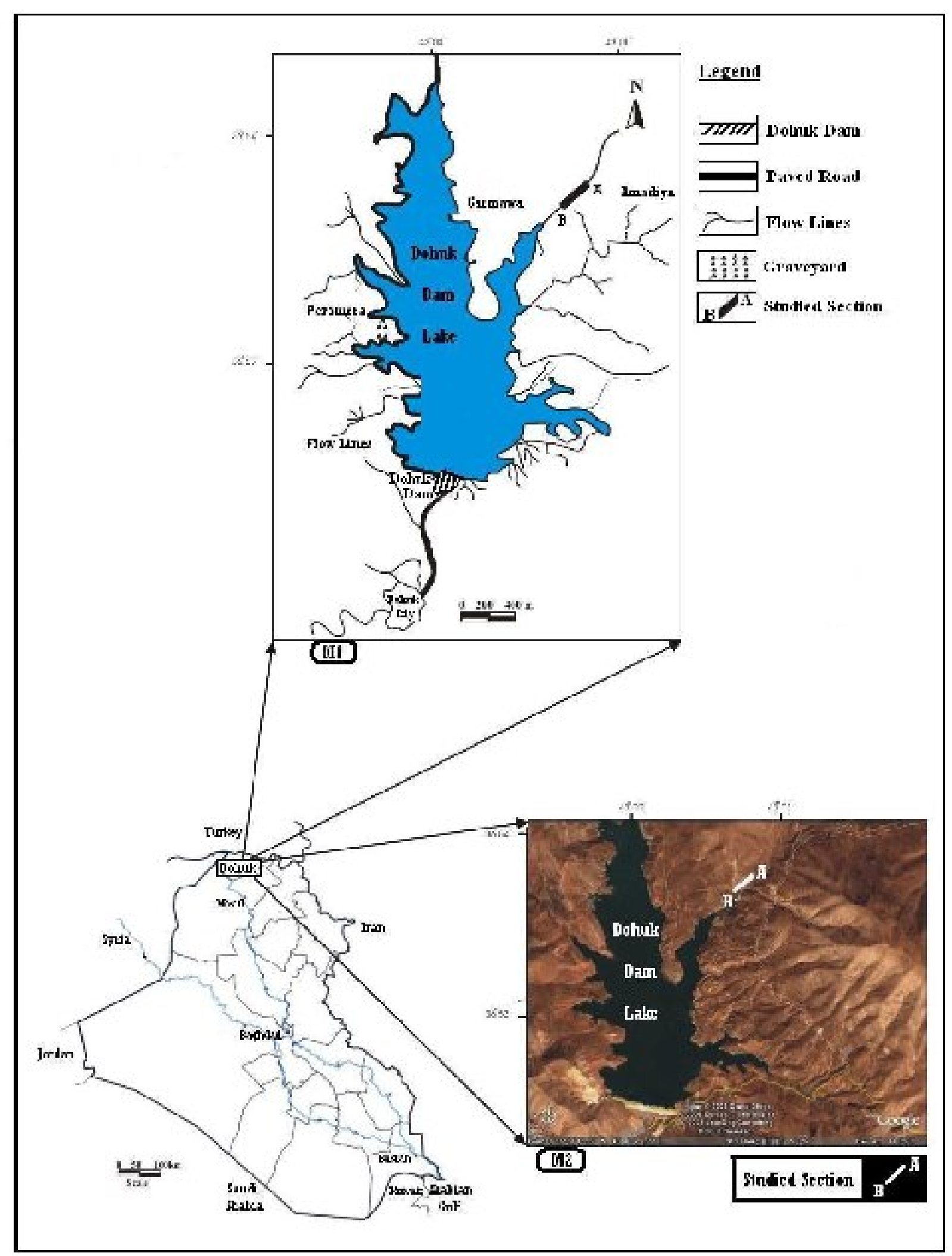

Fig. 1: Location Map (M1) and Satellite Image (from Google Earth) of the Studied Section (M2). 


\section{MATERIALS AND METHODS}

Sixty - three rock samples were collected at $(0.2-3) \mathrm{m}$ intervals from the studied section. Three main methods were used to prepare the samples for biostratigraphic analysis. About 50 thin sections were prepared from hard samples (limestone, marly limestone and conglomerate). About $30 \mathrm{gm}$ of each soft sample was weighed, crushed, boiled for (4 - 6) hours, washed over 230 mesh sieve with tap water, dried and size - sorted using a nest of sieves of $(45,60,80,120,200$ mesh), then ultrasonically agitated for $(5-10)$ seconds. All specimens were picked and mounted on microslides for identification under binocular microscope. The third method is represented by processing some hard samples with acetic acid technique, which is previously used by Reolid and Herrero (2004) to retrieve foraminifera from indurated carbonates. Acetic acid makes a very slow reaction namely (cold - disaggregation) that disaggregate the hard samples and then retrieving the foraminiferal specimens from them. This method include the following procedures:

1. Break an integrate weight of all samples into small fragments.

2. Place the crushed sample in a beaker and cover it with a solution of acetic acid made up of $80 \% \mathrm{CH}_{3} \mathrm{COOH}$ and $20 \% \mathrm{H}_{2} \mathrm{O}$.

3. Keep the sample submerged in the solution for $(3-10)$ hours.

4. Wash the sample with tap water through 230 mesh sieve, dry at $(40-50)^{\circ} \mathrm{c}$ and size - sorted using a nest of sieves, finally pick the specimens and mount on microslides for identification.

\section{BIOSTRATIGRAPHY}

The great abundance and wide distribution of planktonic foraminifera in marine sediments and their rapid evolution during Cretaceous period make them a powerful biostratigraphic tool for global biostratigraphy and accurate local and regional correlation.

In this study, the foraminiferal assemblages of the studied section revealed that planktonic species are abundant within marl and marly limestone beds, whereas they are rare or absent within conglomerate beds and in some limestone beds too (Fig. 4), but larger benthonic foraminifera specially those belonging to genera Orbitoides and Lepidorbitoides are recorded within these beds. Therefore, planktonic and larger benthonic foraminifera have been used for biostratigraphic analysis for the studied section. The systematic investigation of the studied section enabled us to identify forty - eight planktonic species and fifty three benthonic species and subspecies. Based on the geological time scale recorded by Gradstein et al. (2004), the age of planktonic foraminiferal zones has been determined.The identified planktonic foraminiferal biozones were correlated with their equivalent standard biozones in other regions of the world (Fig. 5). Furthermore, these biozones have been correlated locally with previous zonal schemes in Iraq (Fig. 6). In intervals that lack planktonic foraminifera, larger 
benthonic faraminifera were used for recognizing one biostratigraphic zone (Fig. 7). And it is correlated with the equivalent benthonic and planktonic biozones (Fig. 8). Depending on the stratigraphic distribution and relative abundance of planktonic foraminiferal faunas, the studied section is subdivided into four biozones, which confirm a late Campanian age of the section. These biozones are briefly described below starting from older to younger:

\section{- Globotruncanita calcarata Total Range Zone (part) (CF10)}

Definition: This zone is defined by the total range of the index species Globotruncanita calcarata (Cushman).

Age: early late Campanian.

Boundaries: The lower boundary of this zone is not exposed in the studied section, and it is usually marked by the first appearance of the index species Globotruncanita calcarata (Cushman), while its upper boundary is indicated by the disappearance of nominate species.

Thickness: $18.5 \mathrm{~m}$ represented by the samples $(1-16)$.

Discussion: In the studied area, Globotruncanita calcarata Zone represents the oldest outcropping biozone, which includes the lower part of Bekhme Formation. This zone is characterized by high abundance of planktonic foraminiferal species of globular chambers. In addition, keeled planktonic forams also occur, but with a less abundance. Besides the nominate taxon, the predominant species are: Globotruncana linneiana (d' Orbigny), Globotruncana bulloides Vogler, Globotruncana lapparenti Brotzen, Globotruncana arca (Cushman), Globotruncana rosetta (Carsey), Globotruncanita stuarti (de Lapparent), Globotruncanita stuartiformis (Dalbiez), Globotruncanita conica (White), Pseudotextularia elegans (Rzehak), Heterohelix globulosa (Ehrenberg), Globigerinelloides prairiehillensis Pessagno, Rugoglobigerina rugosa(Plummer), Rugoglobigerina macrocephala Bronnimann and Globotruncanella petaloidea (Gandolfi ).

Correlation and Age Determination: The extinction of Globotruncanita calcarata is regarded one of the most important indicators, which had been used to delineate the Campanian - Maastrichtian boundary ( Robaszynski et al., 1984; Caron, 1985 and Sliter, 1989). However, Robaszynski and Caron (1995) in Sari(2006) noted that the Globotruncanita calcarata disappeared before the base of Nostoceras (Nostoceras) hyatti Zone (ammonite zone dating the uppermost Campanian), so the Globotruncanita calcarata Zone might be a little older. As noted by Premoli Silva and Sliter (1994) in Sari(2006 ), the Campanian Maastrichtian boundary was equated to the Chron 32N/Chron 31R boundary and shifted to 71.3 Ma by Hambach (1992)in Sari (2006), that means the Globotruncanita calcarata Zone does 


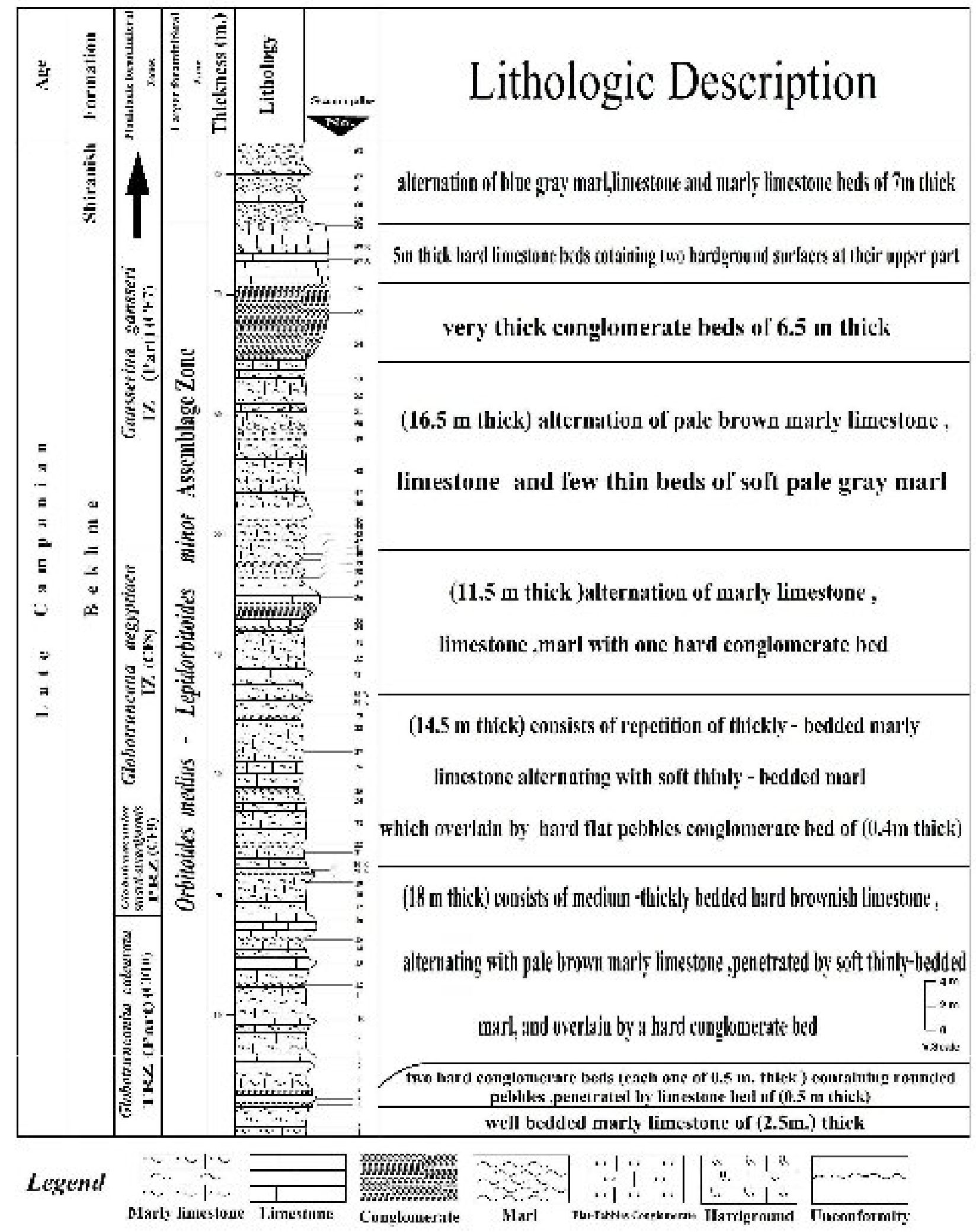

Fig. 2: Litostratigraphic Column of Bekhme Formation and lower Part of Shiranish Formation at the Studied Section. 


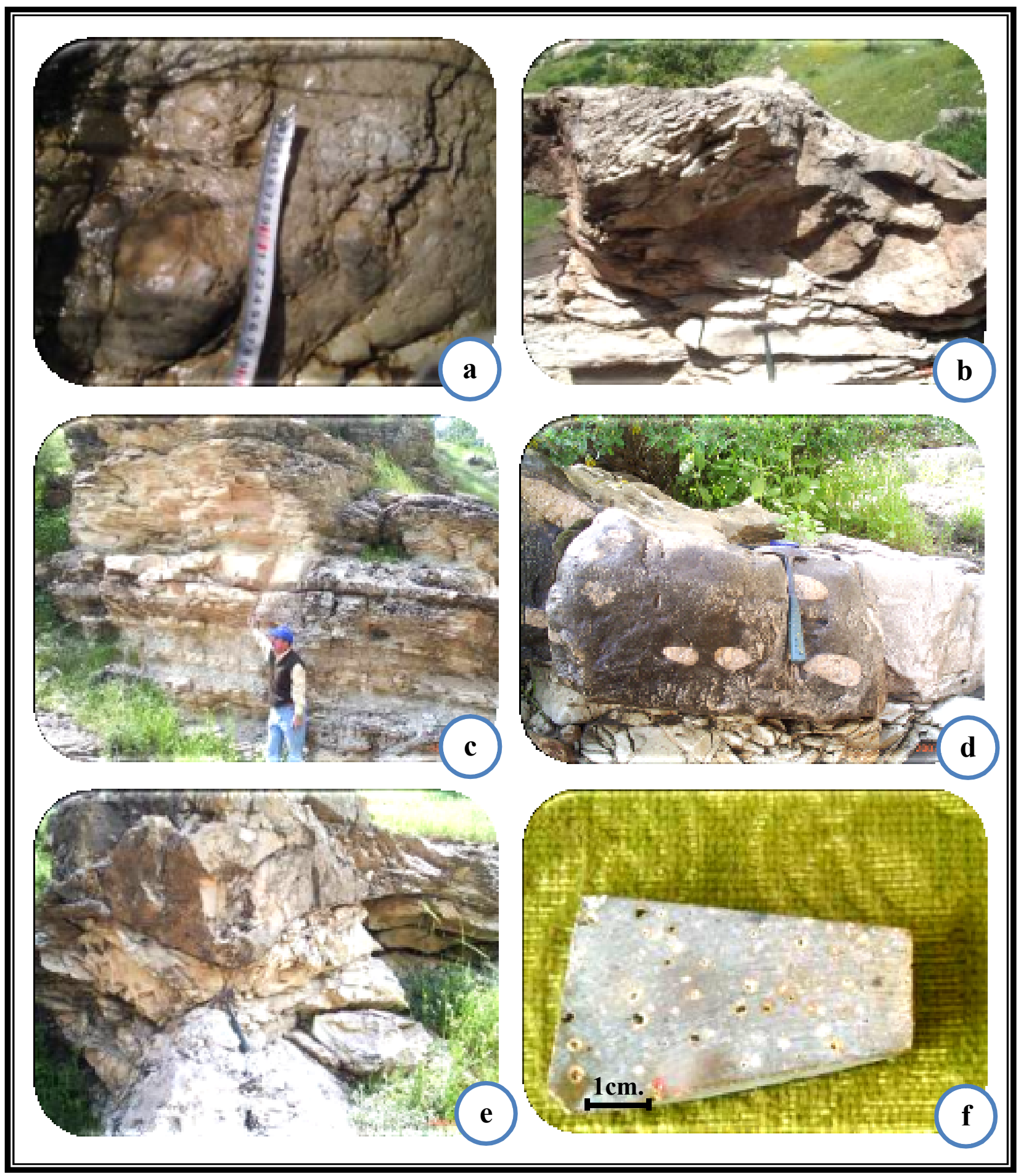

Fig .3: $(\mathrm{a}-\mathrm{e})$ Field photographs of Bekhme Formation showing:

(a)intraformational conglomerate.

(b) limestone beds.

(c) alternationes of marly limestone and marl beds.

(d) flat - pebbles conglomerate.

(e) slumping structures.

(f) polished sample from hardground surface showing the traces of borings. 
not correspond to the uppermost part of the Campanian. Furthermore, the Globotruncanella havanensis and Globotruncana aegyptiaca Zones and even the lower part of the Gansserina gansseri Zone, are all of late Campanian age (Sari, 2006).

The present study showed that the Globotruncanita calcarata Zone is equivalent to the Globotruncana calcarata Zone of Postuma (1971), Caron(1985), Sliter (1989) (in Circum Pacific) and Mogaddam(2002), which corresponds to latest Campanian age. The zone is also correlative to the Globotruncanita calcarata of Li et al. (1999). Gradstein et al. (2004) and Chacon and Chivelet (2005) (in Spain) which support early late Campanian, and it is also equivalent to Radotruncana calcarata Zone that described by (Sari,2006), which dating the same age of this zone .

In Iraq, the current zone is correlated with Globotruncana calcarata - elevate - aegyptiaca Subzone of Kassab (1979) (north of Iraq) who considered it of latest Campanian age. It is equivalent to Globotruncana calcarata Zone of Abawi et al.(1982), to the Globotruncana rosetta Zone of Hammoudi(2000)(north of Iraq), and to the Globotruncanita calcarata Zone of Al-Juboury(2002). The present biozone is also correlative to Globotruncanita calcarata Zone which is determined by Al-Mutwali et al.(2008).

\section{- Globotruncanita stuarti-Globotruncanita stuartiformis Partial Range Zone (CF9).}

Definition: It is a Partial Range Zone that represents the stratigraphic range of the two nominate species between the last occurrence of Globotruncanita calcarata (Cushman) and first appearance of Globotruncana aegyptiaca Nakkady.

Age: middle late Campanian.

Boundaries: The lower boundary of this zone is marked by the last occurrence of Globotruncanita calcarata, whereas its upper boundary is indicated by the first appearance of Globotruncana aegyptiaca.

Thickness: This zone encompasses the middle part (10 m thick) of Bekhme Formation that is represented by the samples $(17-24)$.

Discussion: In this zone, Contusotruncana patelliformis(Gandolfi) makes its first appearance. Other characteristic species include:

Globotruncana bulloides Vogler, Globotruncana insignis Gandolfi, Contusotruncana fornicata (Plummer), Hedbergella holmdelensis Olsson, Archaeoglobigerina blowi Pessagno, Rugoglobigerina hexacamerata Bronnimann, Globotruncanella havanensis (Voorwijk), Heterohelix globulosa (Ehrenberg), Pseudotextularia elegans (Rzehak) and Pseudoguembelina costulata (Cushman). 
Correlation and Age Determination: The present zone is equivalent to the lower part of Globotruncana stuartiformis Zone of Postuma( 1971), to the Globotruncanella havanensis Zone of Caron (1985) and Sliter (1989), which they considered it to be early Maastrichtian in age, and to the Globotruncanella subcarinatus (CF9) Zone, which described from middle late Campanian deposits by Li et al. (1999). This zone is also correlated with the lower part of Globotruncanita stuarti Zone recorded in Iran by Mogaddam (2002), and with Globotruncanella havanensis Zone of Gradstein et al. (2004), which correspond to the suggested age of the present biozone, and equivalent to the Globotruncana falsostuarti Zone that recorded in Spain and Turkey by Chacon and Chivelet(2005) and Sari (2006), respictively.

Locally, in northern Iraq, this zone is equivalent to the lower part of Globotruncana arca -tricarinata - subcircumnodifer Subzone of Kassab( 1979), to the lower part of Rugotruncana subcircumnodifer Subzone recorded by Abawi et al.(1982). The present zone is correlatable with the lower part of Globotruncanella havanensis Zone of Hammoudi(2000), and with Globotruncanella havanensis - Rosita fornicata Zone of Al-Juboury (2002), and it is equivalent to Globotruncanita stuartiformis - stuarti Zone of AlMutwali et al. (2008).

\section{- Globotruncana aegyptiaca Interval Zone (CF8).}

Definition: It represents the stratigraphic range of the index species Globotruncana aegyptiaca Nakkady, which precedes the appearance of Gansserina gansseri (Bolli).

Age: middle late Campanian.

Boundaries: The lower boundary of this zone is marked by the first appearance of the nominate species, whereas its upper boundary is determined by the first appearance of the species Gansserina gansseri (Bolli).

Thickness: This zone occupies the middle part of the studied section $(20.5 \mathrm{~m}$ thick), it is represented by samples (25 - 42).

Discussion: The present zone is characterized by the wide distribution of single keeled planktonic species specially those which recognized by a high convexity of their umbilical side. In addition to the index species, Globotruncanita angulata (Tilev), Globotruncanita subspinosa (Pessagno), Globotruncana dupeublei Caron et al., Globotruncanita atlantica (Caron ), Planoglobulina carseyae (Plummer) and Gublerina cuvillieri Kikoine make their first appearance in this zone. In addition to the former species, the following taxa have been recognized: 
Globotruncana mariei Banner and Blow, Globotruncana esnehensis Nakkady, Globotruncana orientalis El-Naggar, Globotruncana ventricosa White, Globotruncana linneiana (d'Orbigny), Globotruncanita stuarti (de Lapparent), Globotruncanita stuartiformis (Dalbiez), Heterohelix globulosa (Ehrenberg), Rugoglobigerina hexacamerata Bronnimann, Globigerinelloides subcarinata (Bronnimann ) and Gublerina robusta de Klasz.

Correlation and Age Determination: This zone is correlatable with the upper part of Globotruncana stuartiformis Zone, which is described by Postuma (1971) from early Maastrichtian, with Globotruncana aegyptiaca Zone of Caron (1985) and Sliter (1989), which supports uppermost early Maastrichtian. It is equivalent to the upper part of Globotruncanita stuarti Zone that determined by Mogaddam (2002), and to the Globotruncana aegyptiaca (CF8a) and Rugoglobigerina hexacamerata (CF8b) Zones of Li et al.(1999), which represent latest Campanian and early Maastrichtian age. The present zone is also equivalent to the Globotruncana aegyptiaca of Gradstein et al. (2004), which supports the same age of this zone. It is correlated with the upper part of Globotruncana falsostuarti Zone recorded by Chacon and Chivelet (2005), and Sari (2006). In Iraq, Globotruncana aegyptiaca Zone is correlatable with the upper part of Globotruncana arca tricarinata - subcircumnodifer Subzone of Kassab (1979), which is assigned to the early Maastrichtian age. It is equivalent to the upper part of Rugotruncana subcircumnodifer Subzone of Abawi et al.( 1982), to the upper part of Globotruncanella havanensis Zone determined by Hammoudi ( 2000 ). This zone is also equivalent to the Globotruncana aegyptiaca Zone of Al-Juboury (2002) and Al-Mutwali et al. (2008), which supports uppermost early Maastrichtian and latest Campanian, respictively.

\section{- Gansserina gansseri Interval Zone (part) (CF7).}

Definition: It is the interval zone which represents that part of the stratigraphic range of the index species Gansserina gansseri (Bolli) prior to the first appearance of Abathomphalus mayaroensis (Bolli) or Racemiguembelina fructicosa (Egger).

Age: latest Campanian.

Boundaries: The lower boundary of this zone is indicated by the first appearance of the index species Gansserina gansseri, while its upper boundary is not included in current study, because the two index species Abathomphalus mayaroensis (Bolli), Racemiguembelina fructicosa (Egger) are not recognized herein in the studied section. The first appearance of the former taxa have been depended to draw the upper boundary of this zone by (Caron, 1985; Sliter, 1989; and Gradstein et al., 2004 ). 
Thickness: This zone represents the uppermost $34 \mathrm{~m}$ of the investigated section [27 $\mathrm{m}$ ascribed to the Bekhme Formation, and the uppermost $7 \mathrm{~m}$ to the Shiranish Formation]. It is represented by samples (43 - 63 ).

Discussion: This zone spans within the upper part of Bekhme Formation and lower part of Shiranish Formation. The present zone yields abundant and major increase in species diversification, specially those forms characterized by high trochospiral tests, which are mostly ascribed to the genus Contusotruncana. In addition to the nominate taxon, four planktonic taxa show their first appearance in this zone, as follows:

Contusotruncana contusa (Cushman), Contusotruncana plicata (White), Contusotruncana plummerae (Gandolfi ), Contusotruncana walfischensis (Todd), associated with the following planktonic species:

Globotruncana aegyptiaca Nakkady, Globotruncana dupeublei Caron et al., Globotruncana bulloides Vogler, Globotruncana linneiana (d' Orbigny), Globotruncana insignis Gandolfi, Globotruncanita angulata (Tilev), Globotruncanita stuarti (de Lapparent), Globotruncanita stuartiformis (Dalbiez), Globotruncanita elevata (Protzen), Contusotruncana fornicata Plummer, Rugoglobigerina rugosa (Plummer), Heterohelix globulosa (Ehrenberg), Pseudotextularia elegans (Rzehak), Globotruncanella petaloidea (Gandolfi) and Globigerinelloides subcarinata (Bronnimann).

Correlation and Age Determination: The Gansserina gansseri Zone is correlated to the lower part of Gansserina gansseri Zone of Postuma (1971); Caron ( 1985 ); Sliter(1989); and Mogaddam (2002). It is equivalent to Gansserina gansseri Zone (CF7) of Li et al. (1999); Gradstein et al.(2004); Chacon and Chivelet (2005); and Sari (2006). In Iraq, Gansserina gansseri Zone is correlatable with Globotruncana gansseri - bahijae, Gublerina cuvillieri Subzone of Kassab(1979). It is also equivalent to the Globotruncana gansseri Subzone of Abawi et al. (1982), and it is partly equivalent to the Gansserina gansseri Zone of Hammoudi (2000) and AL- Juboury ( 2002). 


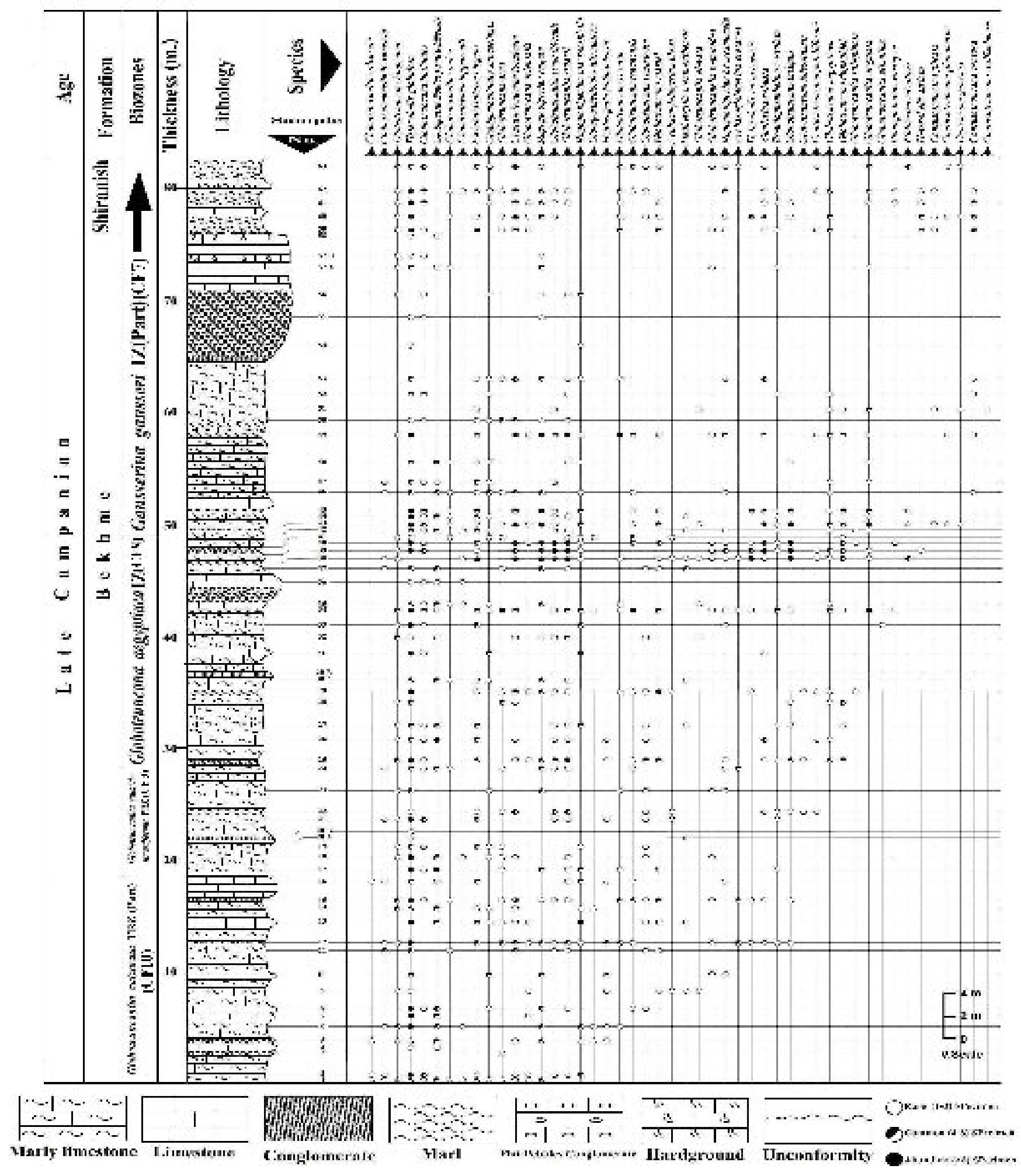

Fig. 4: Biostratigraphy and Range-Chart of Planktonic Foraminifera in the Studied Section. 
Majid M. Al-Mutwali and Layla Y. Al-Haidary
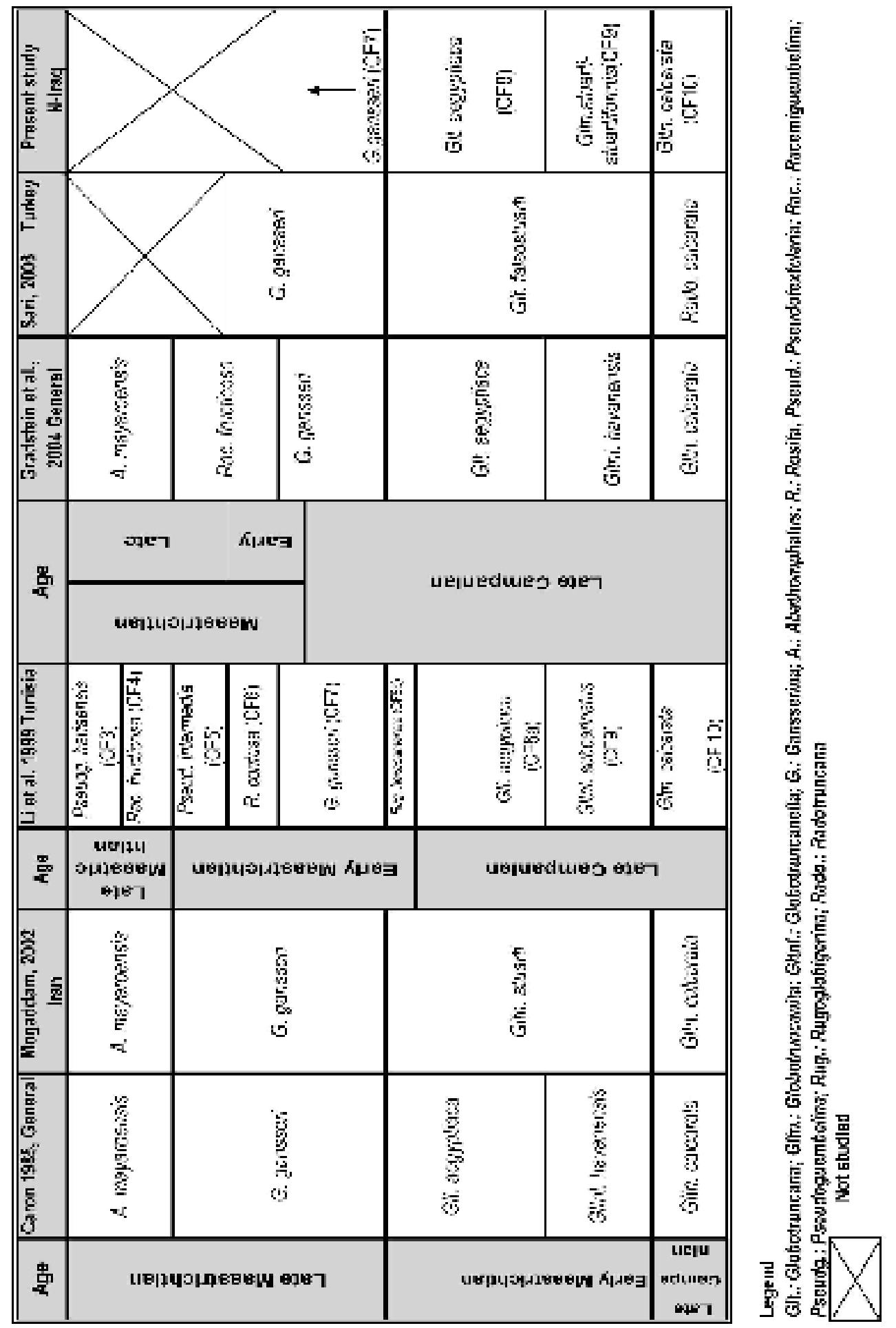

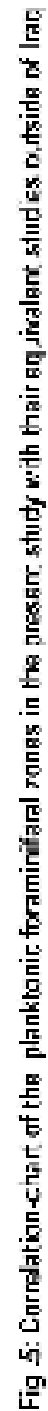




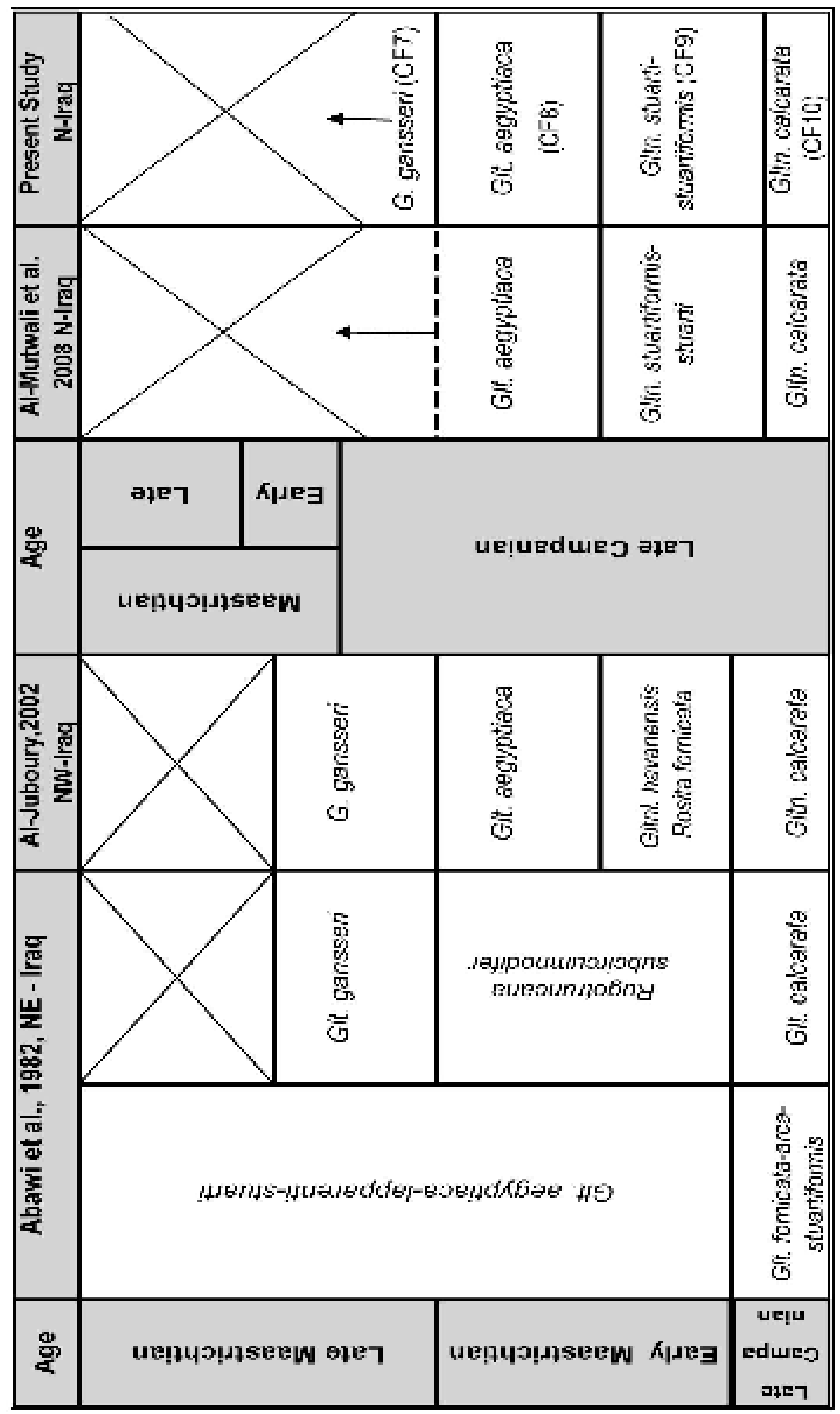

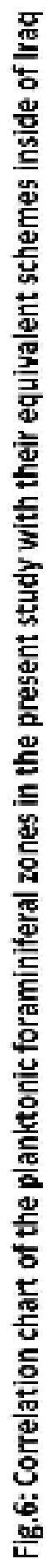


The stratigraphic distribution and relative abundance of larger benthonic foraminiferal fauna within Bekhme Formation facilitated the determination of one benthonic foraminiferal zone:

Orbitoides medius - Lepidorbitoides minor Assemblage Zone.

Definition: This zone represents an assemblage zone of the two nominate taxa and other associated benthonic foraminiferal fauna.

Age: late Campanian.

Thickness: This zone extends within the entire thickness of Bekhme Formation, it is restricted to five intervals, which sporadically appear in Bekhme's successions at levels shown below:

1. The first stratigraphic interval ranges between $2.6-7.0 \mathrm{~m}$ level.

2. The second stratigraphic interval ranges between $21.6-22.2 \mathrm{~m}$ level.

3. The third stratigraphic interval ranges between $36.4-36.8 \mathrm{~m}$ level.

4. The fourth stratigraphic interval ranges between $43-46 \mathrm{~m}$ level.

5. The fifth stratigraphic interval ranges between $64.6-76 \mathrm{~m}$ level.

As mentioned above, it is clear that the total thickness of these stratigraphic intervals attains $19.4 \mathrm{~m}$.

Boundaries: The lower boundary is marked by the first appearance of the nominate species with other associated benthonic fauna, while its upper boundary is marked by the disappearance of these benthonic fauna with the end of Bekhme Formation.

Discussion: This zone is characterized by the common occurrence of the two nominate species, in addition to the following benthonic species:

Omphalocyclus macroporus (Lamarck), Sulcoperculina dickersoni (Palmer), Loftusia morgani Douville, Lenticulina sp., Nodosaria sp., Gavelinella sp., Dorothia bulletta (Carsey), Bolivina incrassata Reuss, Pseudolituonella reicheli Marie, Pyrgo sp., Quinqueloculina sp., Triloculina sp., Spiroloculina sp.

In addition to the benthonic foraminifera, the stratigraphic intervals mentioned above also contain remains of ostracods, algae, pelecypoda (rudist clasts )and few planktonic species, which are represented by the following species:

Heterohelix globulosa (Ehrenberg), Globigerinelloides prairiehillensis Pessagno, Rugoglobigerina rugosa (Plummer), Globotruncanita calcarata (Cushman), Globotruncana arca (Cushman), Hedbergella holmdelensis Olsson, Globotruncana lapparenti Brotzen, Globotruncana bulloides Vogler, Globigerinelloides subcarinata (Bronnimann) and Globotruncanita stuarti (de Lapparent).

Correlation and Age Determination: The Orbitoides medius - Lepidorbitoides minor Zone has been correlated with their equivalent benthonic foraminiferal zones, which are previously recorded by several authors in and outside Iraq (Fig.8). Furthermore, larger benthonic foraminiferal zone has been compared with planktonic zones that are described in the present study. The Orbitoides medius Lepidorbitoides minor Zone is equivalent to Orbitoides media media, Orbitoides 
media megaloformis Subzones and lower part of Orbitoides apiculata gruenbachensis Subzone recorded by Van Gorsel ( 1978) from late Campanian early Maastrichtian age. It is correlated with Orbitoides tissoti - Orbitoides medius Zone and the lower part of Orbitoides apiculatus - Orbitoides medius Zone of Al Mutwali and Abawi ( 2005 ). The Orbitoides medius - Lepidorbitoides minor Zone is also partly equivalent to Orbitoides media - Lepidorbitoides minor Zone of Abdelghany (2003). A comparsion between this zone and planktonic foraminiferal zones have been used by the last author in Emirate and Oman, which who mentioned that this zone can be correlated with the Globotruncana aegyptiaca and lower part Gansserina gansseri interval zones. Therefore, we adopted a similar correlation between this zone and the planktonic foraminiferal zones that we described in this study. It seems to be equivalent to Globotruncanita calcarata, Globotruncanita stuarti - stuartiformis, Globotruncana aegyptiaca and Gansserina gansseri zones. All these zones are assigned to late Campanian.

\section{CONCLUSIONS}

1- In the studied section, Bekhme Formation consists of marly limestone, limestone, conglomerate and marl beds, whereas the lower part of Shiranish Formation is made up of soft marl beds alternating with thin limestone and marly limestone beds.

2- The lower contact of Bekhme Formation is not exposed in the studied section, while the upper contact is stratigraphically unconformable with overlaying Shiranish Formation, where there is a sudden change in lithology between the two formations from brownish hard limestone bed with two hardground surfaces of Bekhme Formation to bluish soft marl beds of Shiranish Formation.

3- Forty - eight species of planktonic foraminifera belonging to fourteen genera, and fifty - three benthonic species and subspecies belonging to forty genera have been recognized.

4- Based on the geological ranges and relative distribution of planktonic foraminifera, the section under investigation has been divided into four biozones. As follows from older at base:

D- Gansserina gansseri Interval Zone (part) (CF7).

C- Globotruncana aegyptiaca Interval Zone (CF8).

B- Globotruncanita stuarti - stuartiformis Partial Range Zone (CF9).

A- Globotruncanita calcarata Total Range Zone (part) (CF10).

5- In Bekhme Formation, one larger benthonic foraminiferal biozone(Orbitoides medius - Lepidorbitoides minor Assemblage Zone), has been recorded, which sporadically appears within five stratigraphic intervals.

6- Depending on the planktonic and benthonic foraminiferal biozones recorded in this study, the age of Bekhme Formation is assigned to late Campanian. 


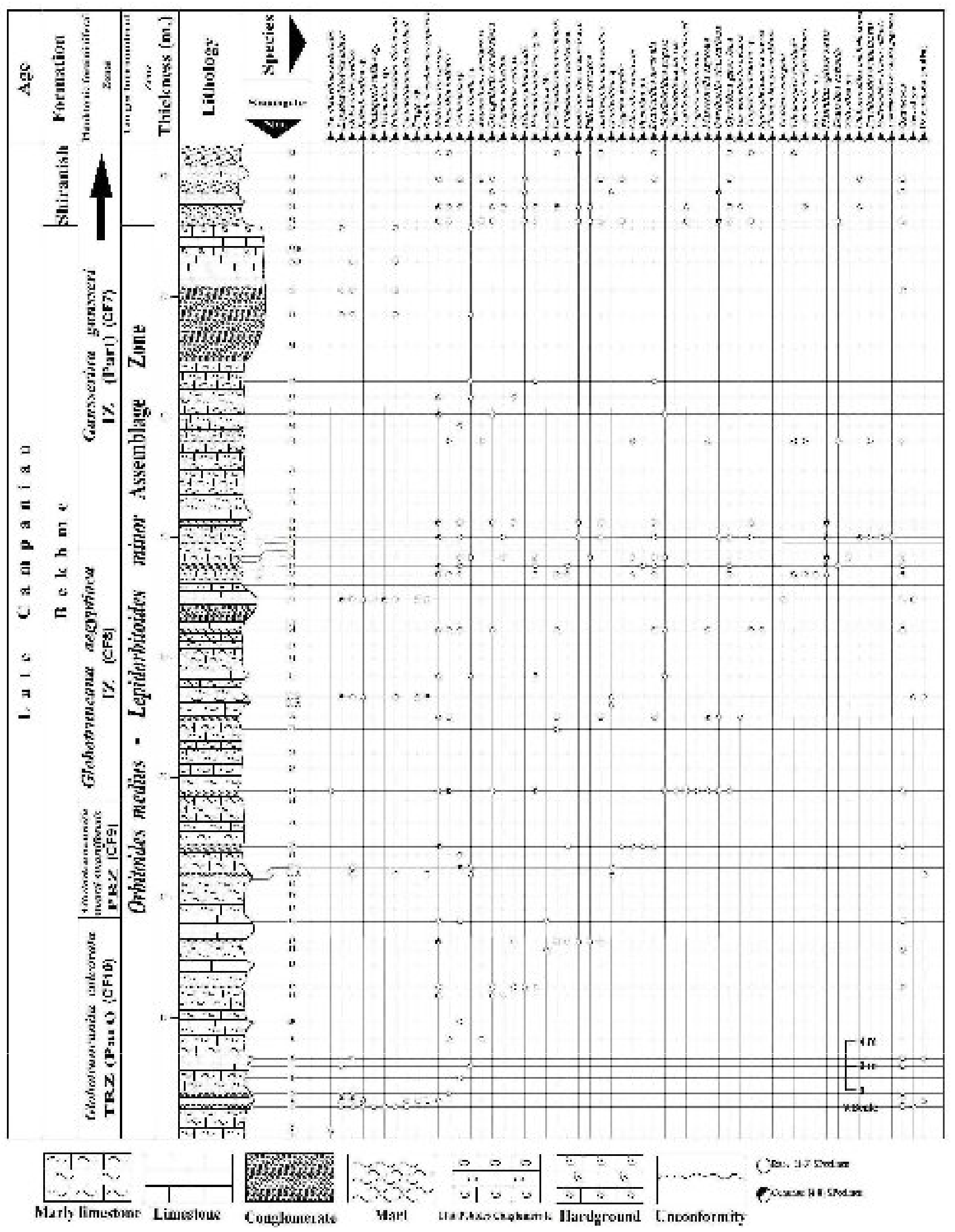

Fig. 7: Biostratigraphy and Range-chart of benthonic foraminifera and other assemblages in the studied section. 


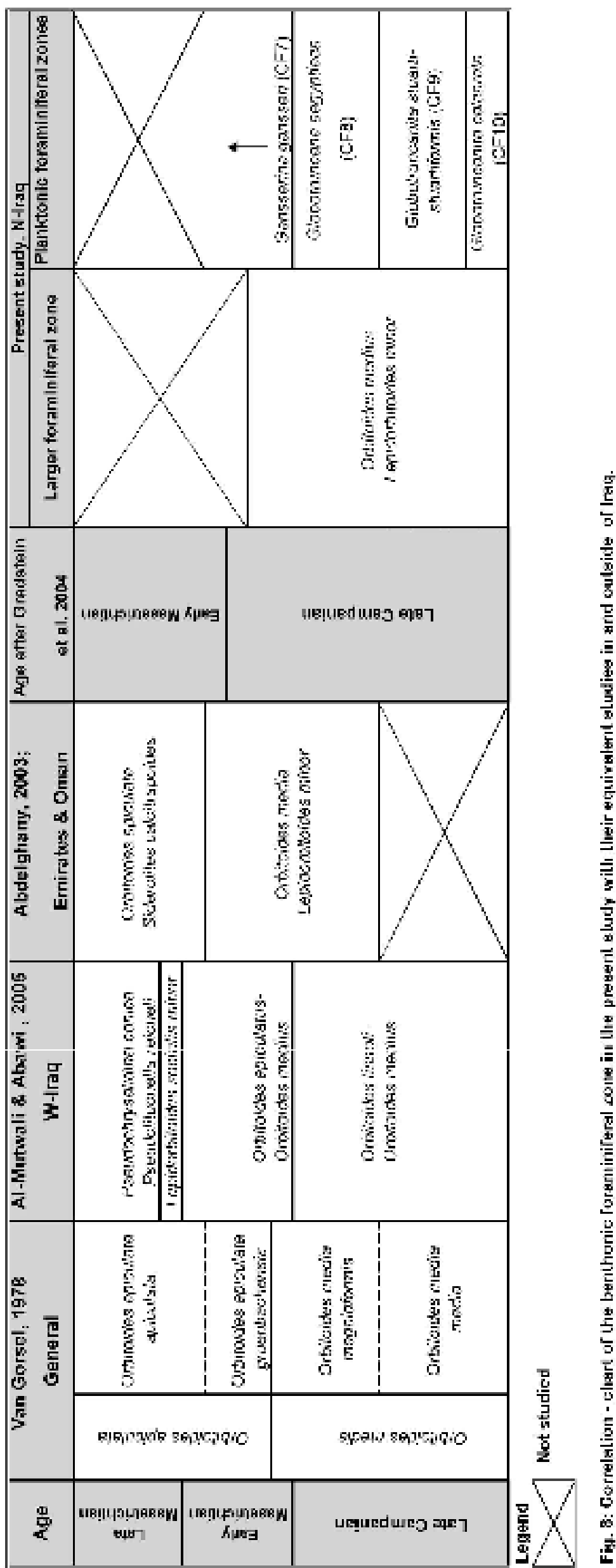


Note :This research is excerpted from the master thesis of Al-Haidary, 2009.

\section{ACKNOWLEDGEMENTS}

We would like to thank Dr. F. S. Al-Omari, Dr. T. S. Abawi, their contribution by reviewing an early draft of this paper, and giving many valuable comments and suggestions. Thanks are extended to Ms. Ghadeer M. Thanon and Mashael K. Abed in Al-Iraqia Journal of Geoscience for designing the final version of this paper.

\section{REFERENCES}

Abawi, T. S., Abdel-Kireem, M. R. and Yousef, G. M., 1982. Planktonic Foraminiferal Stratigraphy of the Shiranish Formation, Sulaimaniah - Dokan Region, Northeastern Iraq. Revista Espanola de Micropaleontologia. Vol. 14, No.1, pp. 153 - 164.

Abdelghany, O., 2003. Late Campanian - Maastrichtian Foraminifera from the Simsima Formation on the Western Side of the Northern Oman Mountains. Cretaceous Research. Vol. 24, pp. 391 - 405.

Al-Haidary, L. Y., 2009. Stratigraphy and Depositional Environment of Bekhme Formation and the Natural of its Contact with Shiranish Formation in Dohuk Area, North of Iraq. Unpublished. M.Sc. Thesis, Mosul University, Iraq. 131p. (In Arabic with English abstract).

Al-Juboury, F. N., 2002. Biostratigraphy of Foraminifera and Paleoenvironment of Shiranish Formation in Sinjar Area, Northwestern Iraq. Unpublished. M.Sc. Thesis, Mosul University, Iraq. 77p. (In Arabic with English abstract).

Al-Mutwali, M. M. and Abawi, T. S., 2005. Stratigraphy of the Tayarat Formation (Upper Cretaceous)in Selected wells, Western Iraq. Rafidain Journal of Science.Vol. 16, No.1, pp.17 - 32 (In Arabic).

Al-Mutwali, M. M., Al-Banna, N. Y. and Al-Ghrear, J. S., 2008. Microfacies and Sequence Stratigraphy of the Late Campanian Bekhme Formation in the Dohuk Area, N. Iraq. Journal of GeoArabia, Vol. 13, No.1, pp. 39 - 54.

Bellen, R. C. Van, Dunnington, H. V., Wetzel, R. and Morton, D. M., 1959. Lexique Stratigraphique International. Asie, Fascule, 10a, Iraq, Paris, 333 p. Buday, T., 1980. The Regional Geology of Iraq, Vol. 1. In: I.I., Kassab and S. Z., Jassim (Eds.), Stratigraphy and Paleogeography. D. G., Geol. Surv. Min. Inves., Baghdad, $445 \mathrm{p}$.

Caron, M., 1985. Cretaceous Planktic Foraminifera, In: H. M., Bolli, J.B., Saunders and K., Perch-Nielsen (Eds.), Plankton Stratigraphy, Cambridge University Press, pp. 17 - 86, 37 Figs.

Chacon, B. and Chivelet, J. M., 2005. Major Palaeoenvironmental Changes in the Campanian to Palaeocene Sequence of Caravaca (Subbetic zone, Spain). Journal of Ibrian Geology, Vol. 31, No. 2, pp. 299 - 310.

Chatton, M. and Hart, E., 1961. Review of the Cenomanian to Maastrichtian Stratigraphy in Iraq. IPR /2/141. 62/6298 (Unpublished report). 
Gradstein, F. M., Ogg, J. G. and Smith, A. G. (Eds.), 2004. Geological Time Scale 2004. Cambridge University Press, 500 p.

Hammoudi, R. A., 2000. Planktonic Foraminiferal Biostratigraphy of the Shiranish Formation (Upper Cretaceous) in Jambur Well No. 13, Northern Iraq. Rafidain Journal of Science, Vol. 11, No. 4, pp. 50 - 58.

Jassim, and Buday, 2006. Late Turonian-Danian Megasequence Apg. In: Jassim and Goff (eds.), Geology of Iraq. Published by Dolin, Prague and Moravian Museum. Brno, $341 \mathrm{p}$.

Kassab, I. I., 1979. The Genus Globotruncana Cushman from the Upper Cretaceous of Northern Iraq. Journal of Geological Society of Iraq. Vol. 12, No. 1, pp. $27-127$.

Li, L., Keller, G. and Stinnesbeck, W., 1999. The Late Campanian and Maastrichtian in Northwestern Tunisia: Palaeoenvironmental Inferences from lithology, Macrofauna and Benthic Foraminifera. Cretaceous Research. Vol. 20, pp. 231 - 252.

Mogaddam, H. V., 2002. Biostratigraphic Study of the Ilam and Gurpi Formations Based on Planktonic Foraminifera in SE of Shiraz, Iran. Journal of Sciences, Islamic Republic of Iran, Vol. 13, No. 4, pp. 339 - 356.

Postuma, J. A., 1971. Manual of Planktonic Foraminifera. Elsevier Publis. Co., Amsterdam, $420 \mathrm{p}$.

Reolid, M. and Herrero, C., 2004. Evaluation of Methods for Retrieving Foraminifera from Indurated Carbonates: Application to the Jurrasic Spongiolithic Limestone Lithofacies of the Prebetic Zone (South Spain). Micropaleontology.Vol.50, No. 3, pp. 307 - 312.

Robaszynski, F., Caron, M., Gonzalez, J. M. and Wonders, A., 1984. Atlas of Late Cretaceous Globotruncanids. Revue de Micropaleontologie, Fascule. 3 - 4, pp. $145-305$.

Sari, B., 2006. Upper Cretaceous Planktonic Foraminiferal Biostratigraphy of the Bey Daglari Autochthon in the Korkuteli Area, Western Taurides, Turkey. Journal of Foraminiferl Research, Vol. 36, No. 3, pp. 241 - 261.

Sliter, W. V., 1989. Biostratigraphic Zonation for Cretaceous Planktonic Foraminifers Examined in thin Section. Journal of Foraminiferal Research, Vol. 19, No. 1,pp. 1 -19.

Van Gorsel, J. T., 1978. Late Cretaceous Orbitoidal Foraminifera. In: R. H., Hedley, C. G., Adams (Eds.). Foraminifera, Vol. 3, Academic Press, 119 p. 


\section{EXPLANATIONS OF PLATE 1}

A: Globotruncanita calcarata (Cushman).Spiral side. Bekhme Formation, sample No. 2.

B: Globotruncanita calcarata (Cushman). Equatorial section. Bekhme Formation, sample No. 2.

C: Globotruncanella havanensis (Voorwijk). Umbilical side. Bekhme Formation, sample No. 38

D: Globotruncanella havanensis (Voorwijk). Axial section. Bekhme Formation, sample No. 47.

E: Globotruncana bulloides Vogler. Spiral side. Shiranish Formation, sample No. 59.

F: Globotruncana bulloides Vogler. Axial section. Bekhme Formation, sample No. 42.

G: Globotruncanita conica (White). Lateral view. Bekhme Formation, sample No. 43.

H: Globotruncanita conica (White). Axial section. Bekhme Formation, sample No. 46.

\section{EXPLANATIONS OF PLATE 2}

A: Contusotruncana fornicata (Plummer). Spiral side. Bekhme Formation, sample No. 12.

B: Contusotruncana fornicata (Plummer). Axial section. Bekhme Formation, sample No. 46.

C: Rugoglobigerina rugosa (Plummer). Axial section. Bekhme Formation, sample No. 46.

D: Globigerinelloides subcarinata (Bronnimann). Side view. Bekhme Formation, sample No. 34.

E: Globigerinelloides subcarinata (Bronnimann). Lateral view. Bekhme Formation, sample No. 34.

F: Globigerinelloides subcarinata (Bronnimann). Axial section. Bekhme Formation, sample No. 46.

G: Globotruncanita stuartiformis (Dalbiez). Spiral side. Bekhme Formation, sample no. 43.

H: Globotruncanita stuartiformis (Dalbiez). Axial section. Bekhme Formation, sample No. 21.

\section{EXPLANATIONS OF PLATE 3}

A: Globotruncanita stuarti (de Lapparent). Spiral side. Bekhme Formation, sample No. 40.

B: Globotruncanita stuarti (de Lapparent). Axial section. Bekhme Formation, sample No. 42.

C: Globotruncana mariei Banner and Blow. Umbilical side. Bekhme Formation, sample No. 25. 
D: Globotruncanita elevata (Protzen). Umbilical side. Bekhme Formation, sample No. 51.

E: Globotruncana aegyptiaca Nakkady. Umbilical side. Bekhme Formation, sample No. 25.

F: Globotruncana aegyptiaca Nakkady. Axial section. Bekhme Formation, sample No. 52.

G: Globotruncana falsostuarti Sigal. Spiral side. Bekhme Formation, sample No. 29.

H: Pseudoguembelina costulata (Cushman). Peripheral view. Bekhme Formation, sample No. 43.

\section{EXPLANATIONS OF PLATE 4}

A: Globotruncana insignis Gandolfi. Spiral side. Bekhme Formation, sample No. 25.

B: Globotruncana insignis Gandolfi. Side view. Bekhme Formation, sample No. 25.

C: Contusotruncana contusa (Cushman). Spiral side. Shiranish Formation, sample No. 59.

D: Globotruncana dupeublei Caron et al. Spiral side. Bekhme Formation, sample No. 38.

E: Globotruncanita subspinosa (Pessagno). Umbilical side. Bekhme Formation, sample No. 29.

F: Heterohelix globulosa (Ehrenberg). Side view. Bekhme Formation, sample No. 15.

G: Planoglobulina carseyae (Plummer). Side view. Bekhme Formaion, sample No. 40.

H: Gublerina cuvillieri Kikoine. Side view. Shiranish Formation, sample No. 63.

\section{EXPLANATIONS OF PLATE •}

A: Gansserina gansseri (Bolli). Spiral side. Bekhme Formation, sample No. 43.

B: Gansserina gansseri (Bolli). Umbilical side. Bekhme Formation, sample No. 43.

C: Orbitoides medius (d'Archiac). Subaxial section. Bekhme Formation, sample No. 36.

D: Orbitoides medius (d'Archiac). Equatorial section. Bekhme Formation, sample No. 20A.

E: Lepidorbitoides minor (Schlumberger). Axial section. Bekhme Formation, sample No. 30B.

F: Sulcoperculina dickersoni (Palmer). Axial section. Bekhme Formation, sample No. 36.

G: Pyrgo sp. Bekhme Formation, sample No. 30B.

H: Omphalocyclus macroporus (Lamarck). Axial section.Bekhme Formation, sample No. 36. 


\section{EXPLANATIONS OF PLATE 6}

A: Loftusia morgani Douville. Equatorial section. Bekhme Formation, sample No. 36.

B: Dentalina catinula Reuss. Bekhme Formation, sample No. 49.

C: Bolivina incrassata Reuss. Side view. Bekhme Formation, sample No. 25.

D: Dorothia bulletta (Carsey). Side view. Shiranish Formation, sample No. 63.

E: Nodosaria sp. Bekhme Fromation, sample No. 34.

F: Lagena apiculata (Reuss). Bekhme Formation, sample No. 40.

G: Cibicidoides voltziana (d'Orbigny). Umbilical side. Bekhme Formation, sample. No. 15.

H: Bolivinoides draco draco (Marsson). Bekhme Formation, sample. No. 43.

\section{EXPLANATIONS OF PLATE 7}

A: Allomorphina halli Jennings. Shiranish Formation, sample No. 59.

B: Bathysiphon alexanderi Cushman. Shiranish Formation, sample No. 63.

C: Cibicides excavata Brotzen. Spiral side. Bekhme Formation, sample No. 38.

D: Cibicides excavata Brotzen. Umbilical side. Bekhme Formation, sample No. 38.

E: Lenticulina navicula(d'Orbigny). Side view. Bekhme Formation, sample No. 39.

F: Neoflabellina jarvisi (Cushman). Side view. Bekhme Formation, sample No. 25.

G: Gavelinella clementiana (d'Orbigny). Umbilical side. Bekhme Formation, sample No. 25.

H: Marssonella oxycona (Reuss). Side view. Bekhme Formation, sample No. 29.

\section{EXPLANATIONS OF PLATE 8}

A: Ammodiscus previanus. Side view. Bekhme Formation, sample No. 49.

B: Planulina spissocostata Cushman. Bekhme Formation, sample No. 39.

C: Gyroidina girardana (Reuss). Umbilical side. Bekhme Formation, sample No. 38.

D: Pyrulinoides acuminatus (d'Orbigny). Bekhme Formation, sample No. 49.

E: Gaudryina pyramidata Cushman. Side view. Bekhme Formation, sample No. 34.

F: Bolivinoides decorata gigantea Hiltermann and Koch. Bekhme Formation, sample No.43.

G: Clast of rudist. Bekhme Formation, sample No. 30B.

H: Ostracoda. Bekhme Formation, sample No. 4. 
PLATE 1

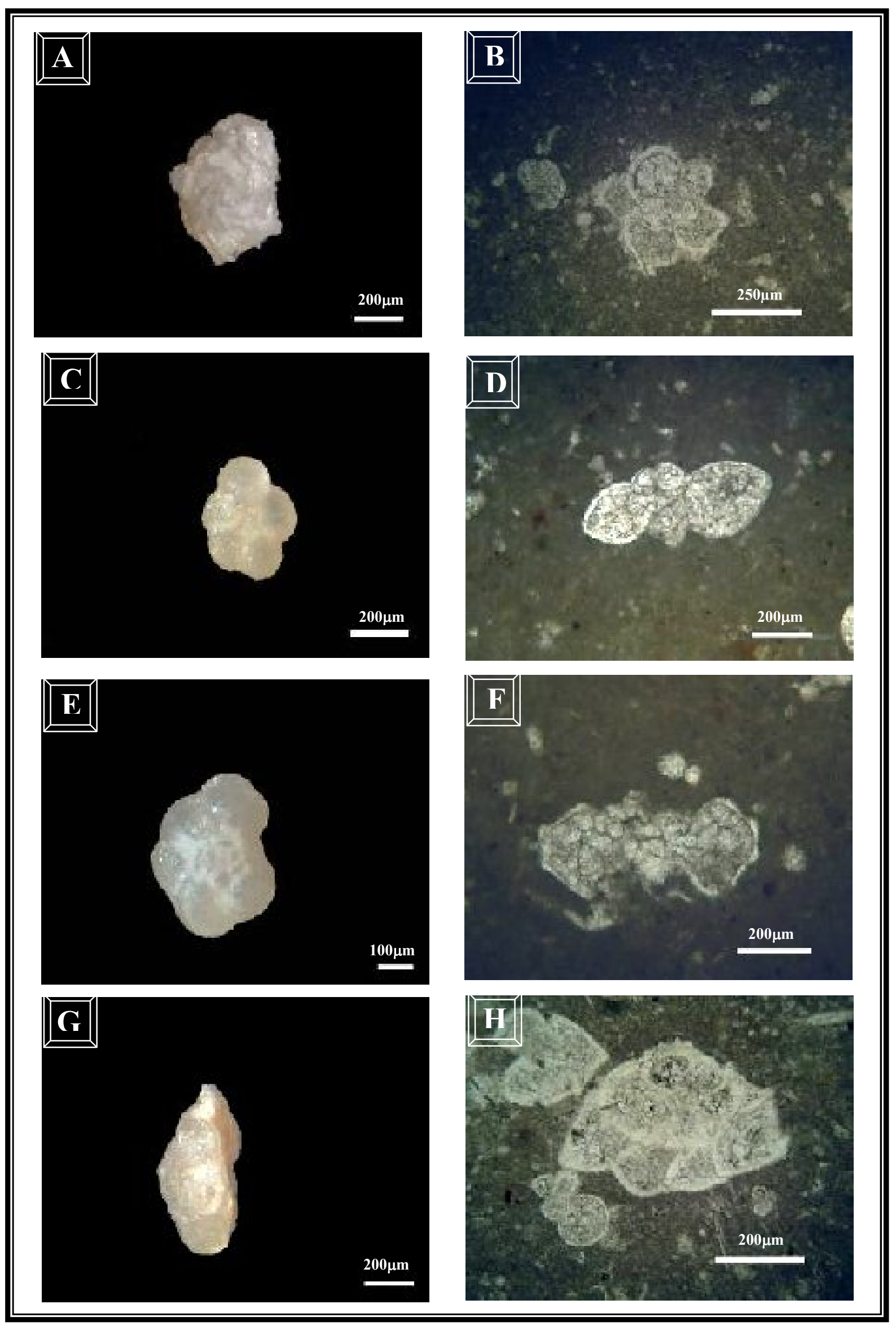


Majid M. Al-Mutwali and Mazin A. AL-Doori

PLATE 2

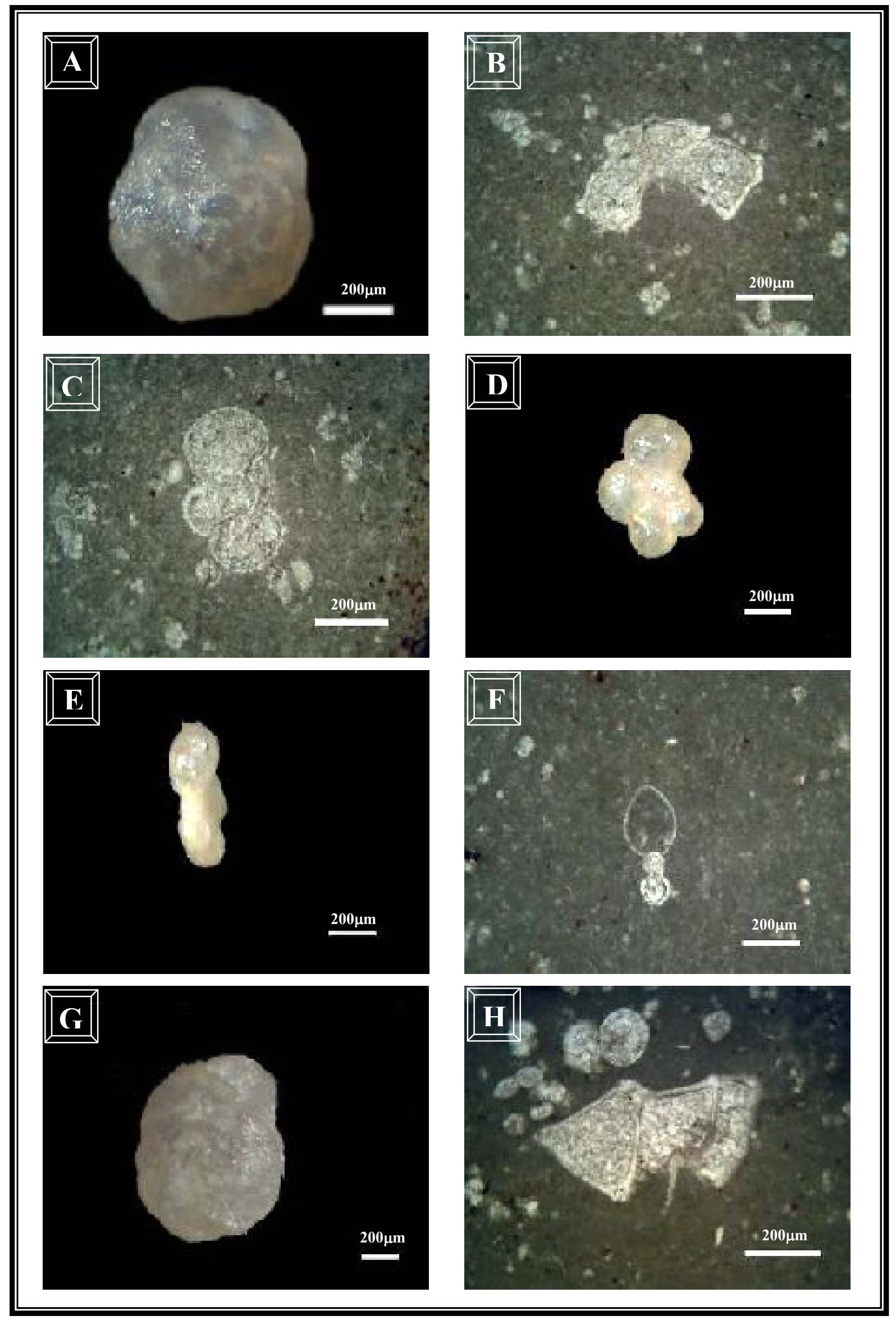


PLATE 3

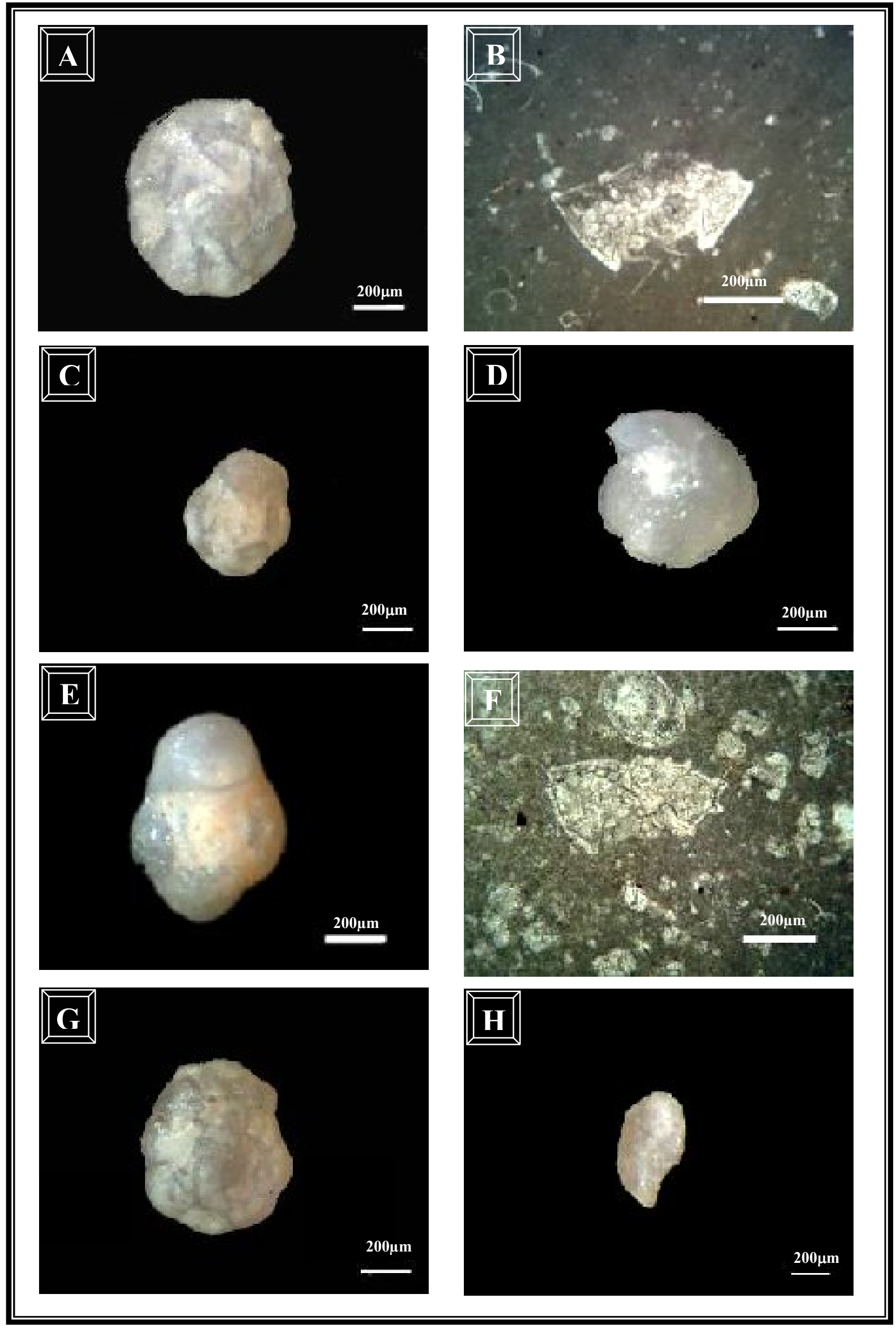


Majid M. Al-Mutwali and Mazin A. AL-Doori

\section{PLATE 4}

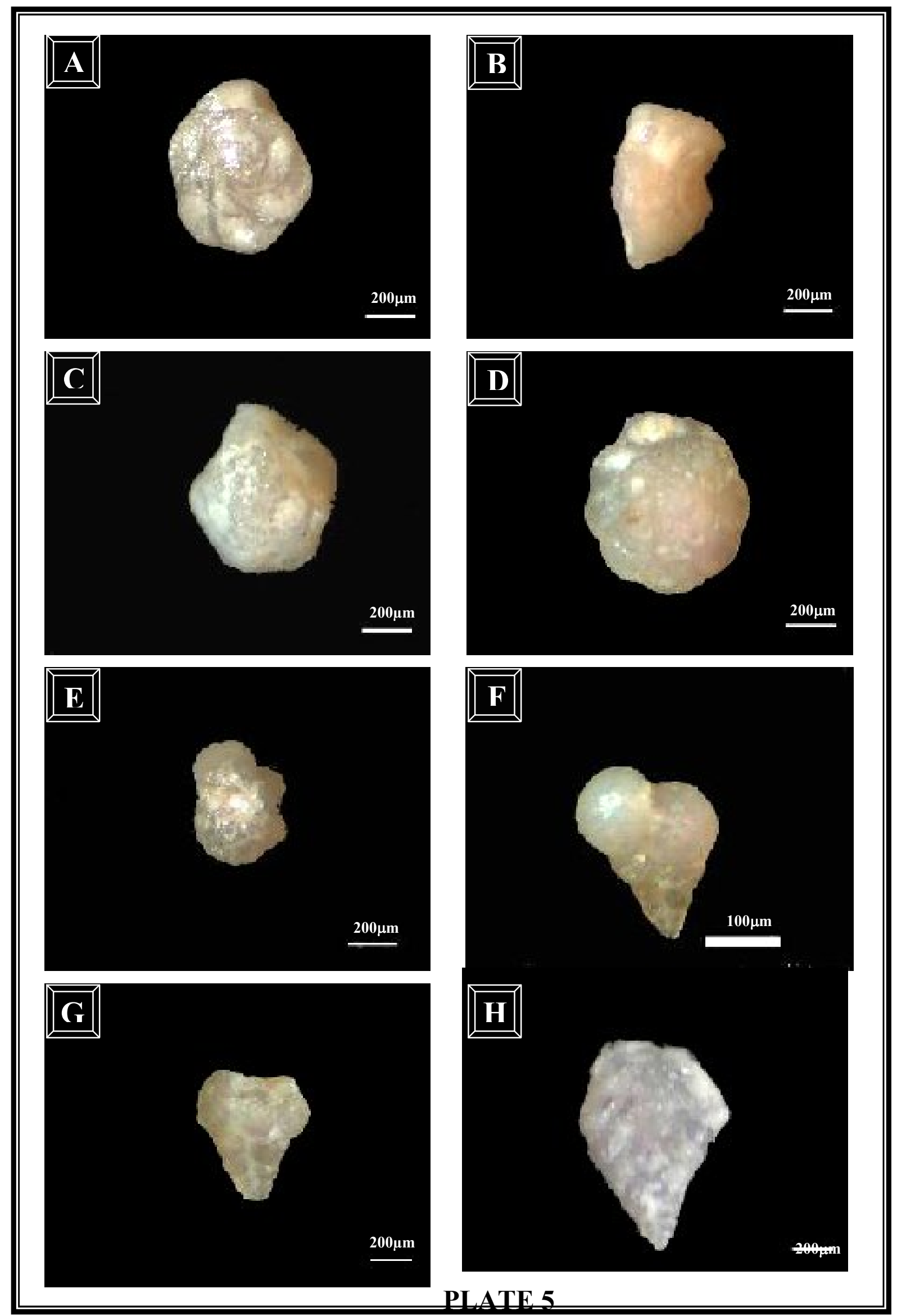




\section{PLATE 5}

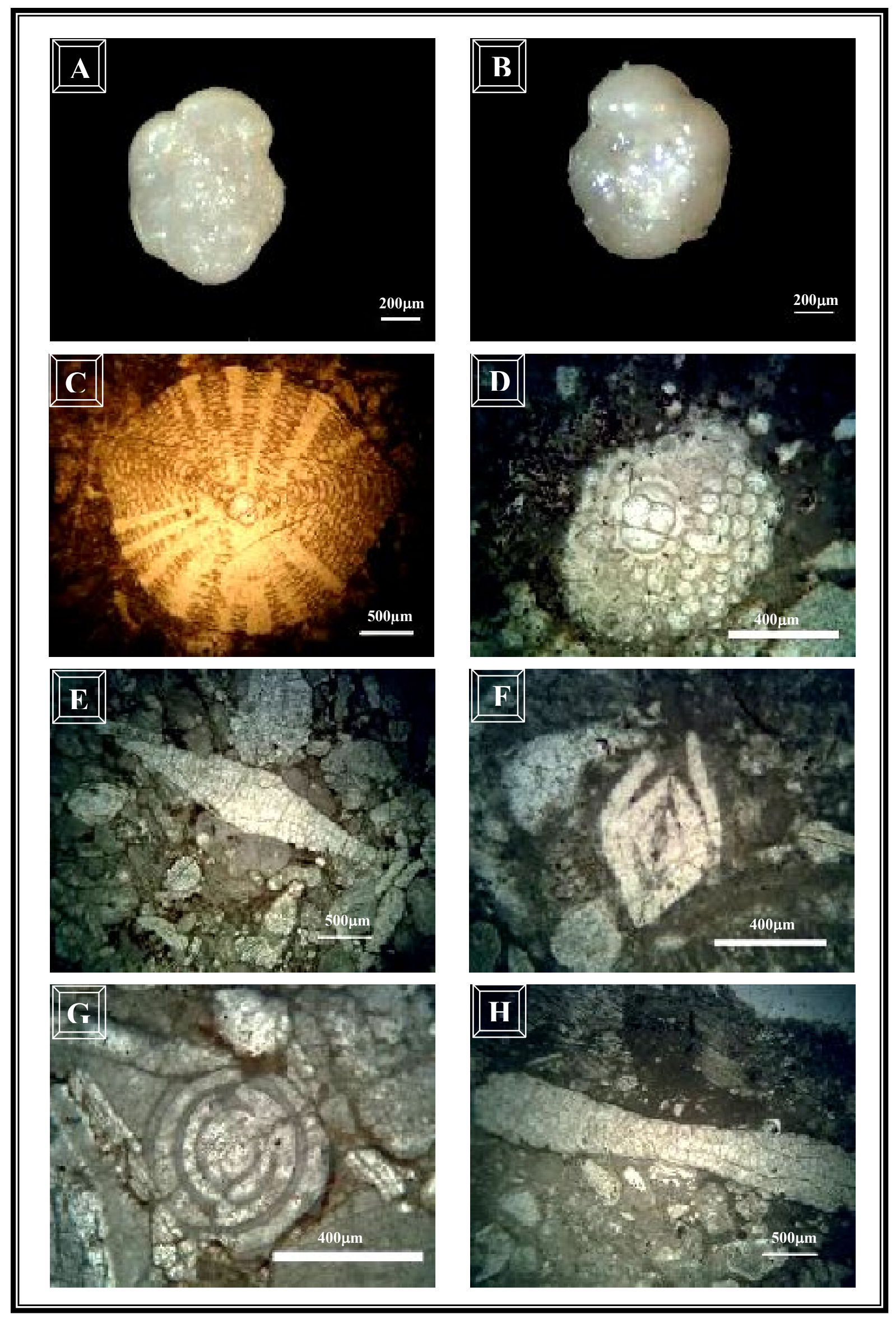


Majid M. Al-Mutwali and Mazin A. AL-Doori

PLATE 6

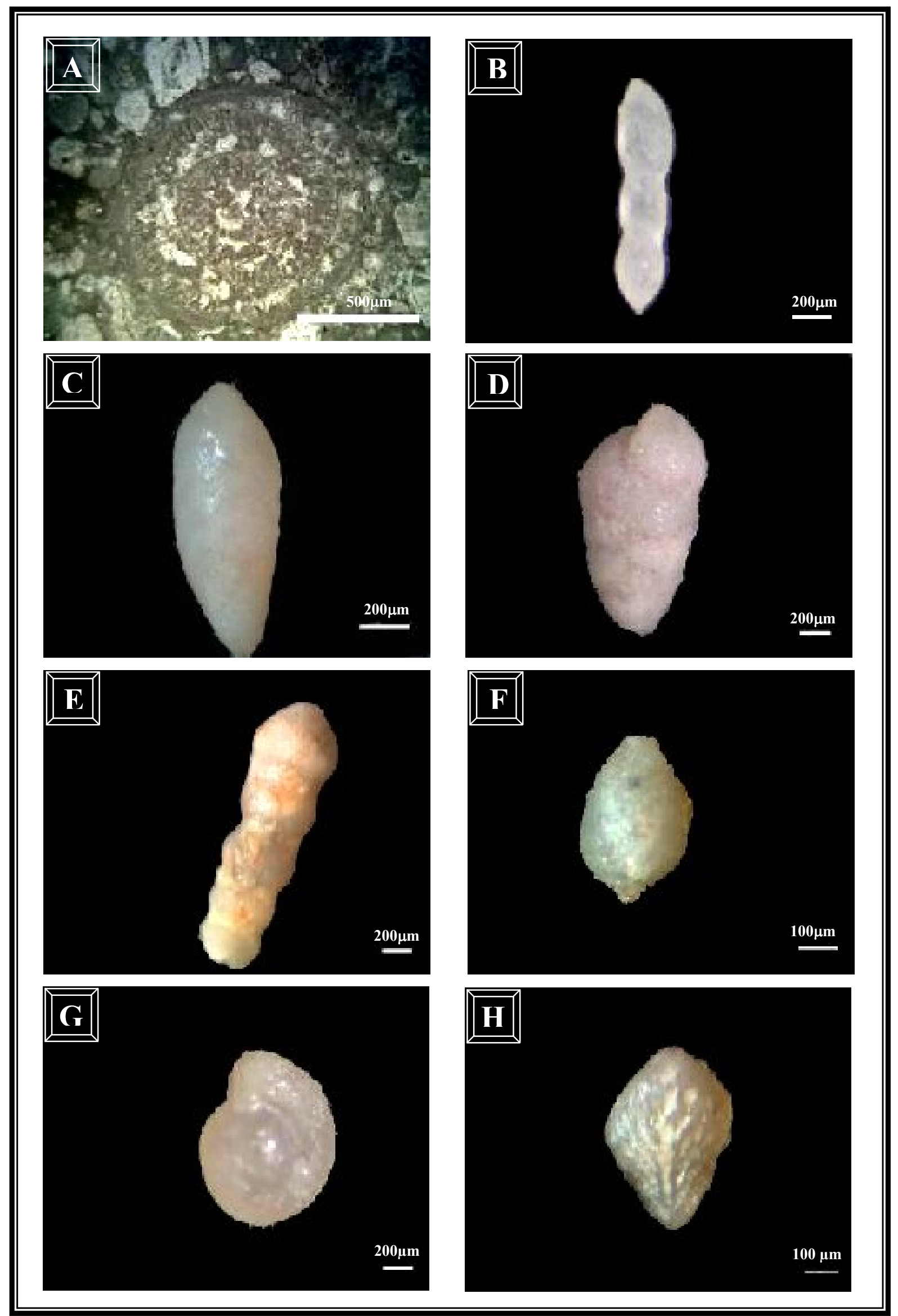




\section{PLATE 7}

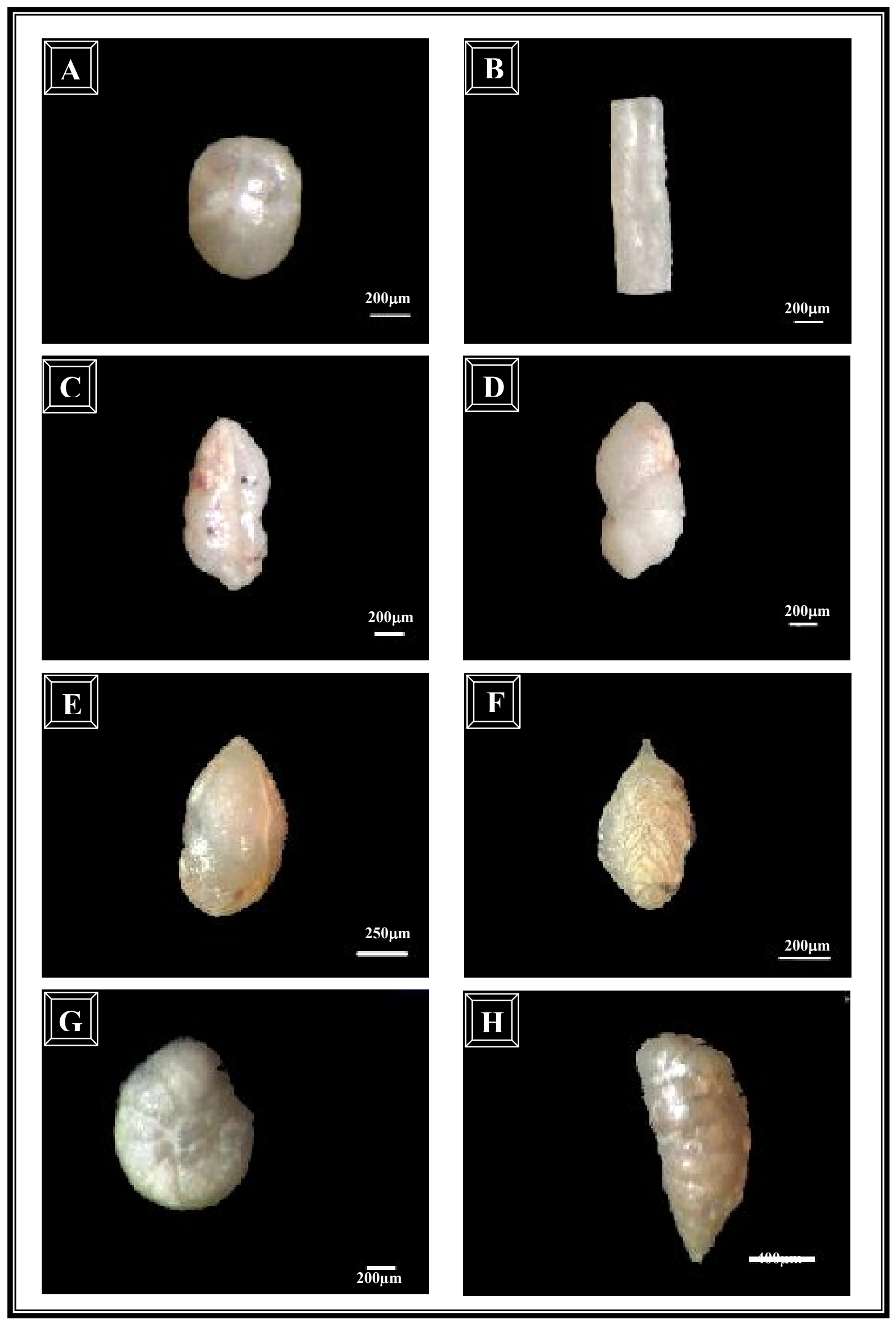


Majid M. Al-Mutwali and Mazin A. AL-Doori

PLATE 8

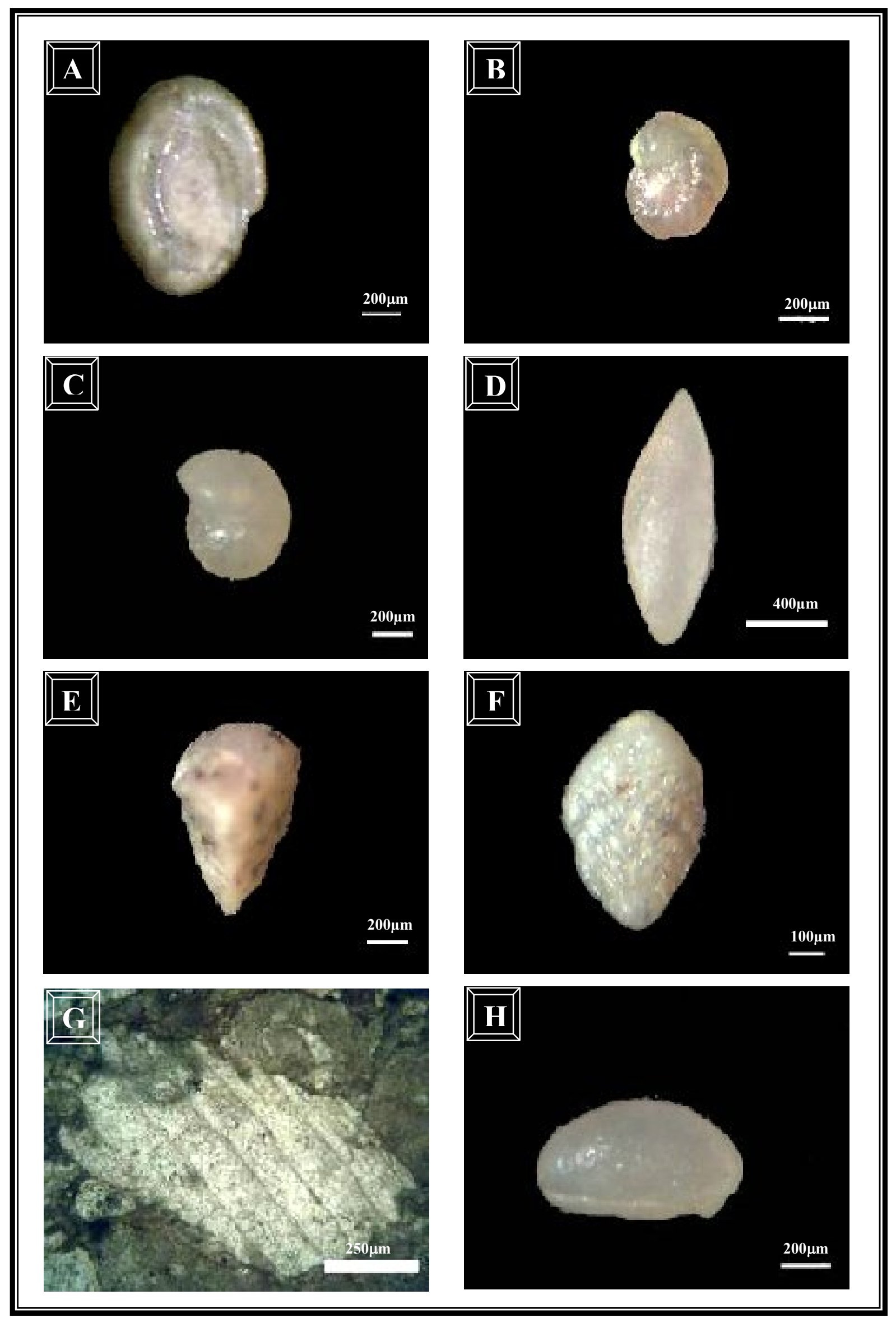

